\title{
АНАЛІЗ РЕЗУЛЬТАТІВ ФОРМУВАЛЬНОГО ЕТАПУ ПЕДАГОГІЧНОГО ЕКСПЕРИМЕНТУ ЩОДО ВПРОВАДЖЕННЯ МОДЕЛІ ПІДГОТОВКИ БАКАЛАВРІВ 3 КІБЕРБЕЗПЕКИ В УМОВАХ ОСВІТНЬО-ЦИФРОВОГО СЕРЕДОВИЩА
}

Резюме
В статті представлені аналіз результатів формувального етапу педагогічного експерименту щодо впровадження моделі підготовки бакалаврів з кібербезпеки в умовах освітньо-ицифрового середовищча. Зазначено, щчо бакалаврам з кібербезпеки подавалася технологія навчання у курсах такого типу, зокрема, надавалися методики та електронний супровід, інтерактивні лекції, навчальні аудіокниги, презентації з профільних дисцзиллін, відеолекиії, онлайн-транслячії, електронні он-лайн калькулятори, масове та дистаниійне навчання, ҮоиТиве канали з інтерактивом для самоперевірки отриманих знань, мережеві тренажери для програмування, колаборативні освітні платформи, колаборативне навчання у мобільних додатках, колаборативні онлайнплатформи, віртуальні моделі $і$ онлайн-лабораторії, тривимірна графіка середовища для візуального програмування, обробки даних, чат-боти. Дослідження здійснювалося з дотриманням низки вимог, основними з яких $\epsilon$ такі: дотримання методики та термінів проведення експерименту (тривалість у часі, здійснення корекції організаџї та відтворення результатів); обгрунтування експериментальної бази дослідження. Експериментальна робота проводилася протягом $n$ 'яти років. В експерименті брало участь 879 бакалаврів з кібербезпеки. Розглянуто отримані результати сформованої готовності бакалаврів з кібербезпеки в умовах освітньоцииррового середовища за визначеними критеріями у контрольних та експериментальних групах до i після експерименту. Рівні сформованості готовності бакалаврів з кібербезпеки в умовах освітньо-цифрового середовища до професійної діяльності за мотивачійним, інтеграчійним, діяльнісноопераційним та творчим критерієм у контрольних та експериментальних групах до $i$ після експериментального дослідження представлені у вигляді розрахункових таблищь. Отримані результати експериментального дослідження надають можливість стверджувати, щуо конструктивна модель підготовки бакалаврів з кібербезпеки в умовах освітньо-циифрового середовища с ефективною.

Ключові слова: бакалавр $з$ кібербезпеки; конструктивна модель підготовки; модель; освітньо-цифрове середовище; педагогічний експеримент, середовище.

Вступ. В наш час кіберзлочинці, які можуть бути представниками різних країн, захоплюють контроль над чужими комп’ютерами, гаджетами, програмними продуктами, запускаючи відповідні програми проти певних 
сайтів, інформаційних ресурсів чи певного контенту мобільних додатків. Технологічний розвиток сучасного кіберпростору вимагає належно підготовлених фахівців з кібербезпеки. Сучасна система підготовки бакалаврів 3 кібербезпеки потребує оновлення методик та удосконалення технологій в системі вищої освіти. 3 цією метою була розроблена конструктивна модель підготовки бакалаврів з кібербезпеки в умовах освітньо-цифрового середовища, закладає в основу потреби сьогодення та ключові педагогічні аспекти підготовки фахівців означеної категорії (Самойленко, Конструктивна модель підготовки бакалаврів з кібербезпеки в умовах освітньо-цифрового середовища, 2020). Модель включає в себе мету, засіб і результат моделювання, яке $\epsilon$ характеристикою якості об'єкта дослідження і спосіб отримання інформації про результативність системи професійної підготовки. (Самойленко, 2016; Самойленко, 2020). Модель підготовки бакалаврів 3 кібербезпеки в умовах освітньо-цифрового середовища складається 3 п’яти конструктів: цільовий, концептуальний, змістовий, діяльнісно-технологічний та результативнокоригуючий. Мета моделі полягає в тому, щоб сформувати готовність бакалаврів 3 кібербезпеки в умовах освітньо-цифрового середовища до професійної діяльності. Результатом конструктивної моделі підготовки бакалаврів 3 кібербезпеки в умовах освітньо-цифрового середовища $\epsilon$ сформована готовність у бакалаврів з кібербезпеки до професійної діяльності. (Самойленко, Критерії формування готовності бакалаврів 3 кібербезпеки до професійної діяльності: педагогічний аспект, 2020). Але сформована модель має лише теоретичне обгрунтування і потребує апробації.

Метою статті є оприлюднення результатів формувального експерименту впровадження конструктивної моделі підготовки бакалаврів 3 кібербезпеки в умовах освітньо-цифрового середовища.

До завдань дослідження віднесено:

1. Співставлення рівнів сформованості готовності бакалаврів 3 кібербезпеки в умовах освітньо-цифрового середовища до професійної діяльності за мотиваційним, інтеграційним, діяльнісно-операційним та творчим 
критерієм у контрольних та експериментальних групах до $\mathrm{i}$ після експериментального дослідження.

2. Статистична перевірка отриманих результатів.

Методи та методики дослідження. На етапі формувального етапу педагогічного дослідження здійснювалися аналіз, порівняння й узагальнення результатів експериментально-дослідної роботи як до експерименту, так і після нього за допомогою апарату математичної статистики, запропонованого О. В. Сидоренко (2000). Це дало можливість порівняти вихідні та прикінцеві характеристики процесу підготовки, довести ефективність запровадження запропонованої конструктивної моделі підготовки бакалаврів 3 кібербезпеки в умовах освітньо-цифрового середовища. На основі використаних методів дослідження сформульовані загальні висновки i рекомендації щодо впровадження теоретичних і практичних результатів дослідження в освітній процес педагогічних закладів вищої освіти, визначені перспективи подальших наукових пошуків у сфері досліджуваної проблеми.

До і після експерименту визначення рівнів сформованості готовності бакалаврів 3 кібербезпеки в умовах освітньо-цифрового середовища до професійної діяльності перевірявся за допомогою тестування, анкетування, комплексних контрольних робіт, результатів атестації, сесійного контролю, захисту магістерських робіт.

Виявлення рівня готовності бакалаврів 3 кібербезпеки до професійної діяльностіза кожним із критеріїв відбувалося за принципом: якщо середнє значення відповідних компонентів знаходиться в межах від $0 \%$ до 25\%, то присвоюється початковий рівень готовності магістрантів до освітньо-наукової діяльності в умовах масових відкритих дистанційних курсів, якщо показник перебуває у межах від 25\% до 50\% - то призначається середній рівень, якщо від $50 \%$ до 75\% - достатній рівень, якщо від 75\% до 100\% - високий рівень.

Упровадження конструктивної моделі підготовки бакалаврів 3 кібербезпеки в умовах освітньо-цифрового середовища відбувалося на основі попередньої роботи як із бакалаврами, так і з викладачами університетів. Для зазначених категорій були розроблені відкриті дистанційні курси, створені 
методичні рекомендації та посібники щодо розробки, впровадження та використання авторських технологій. Після завершення констатувального експерименту бакалаврами контрольної групи було запропоновано самостійно вивчати методичні рекомендації, підібрати засоби в умовах освітньо-цифрового середовища, які відповідають напряму їх підготовки та пройти навчання. 3 цією метою для бакалаврів з кібербезпеки експериментальної групи було підібрано та адаптовано перелік дистанційних курсів, які узгоджувалися 3 навчальним планом та робочими програмами їх підготовки.

Визначено критерії готовності бакалаврів з кібербезпеки до професійної діяльності в умовах освітньо-цифрового середовища. Мотиваційний, який характеризується вмотивованістю майбутніх бакалаврів 3 кібербезпеки на професійну підготовку та використання сучасних технологій та чітким формулюванням мети та завдань в процесі вивчення технологій інформаційної безпеки при розробці систем керування базами даних в умовах освітньоцифрового середовища. Інтеграційний - характеризується знаннями основних принципів поєднання освітнього аудиторного процесу 3 навчанням iз застосуванням дистанційних систем цифрового середовища та умінням підібрати методи, програмні засоби для здійснення програмування, створення $\mathrm{i}$ реалізації продуктів віртуального простору. Діяльнісно-операційний характеризується умінням формувати аналітичні здібності та здатність ділитися власно-набутими знаннями 3 іншими учасниками навчального процесу на основі участі в комунікаційних цифрових середовищах та здатністю формувати продукти професійної діяльності - розробок, методик тощо. Творчий здатністю проектувати цифрового технологічного середовища 3 метою набуття компетентностей та умінням здійснювати технологічний процес щодо створення освітнього контенту за певним запитом у відповідності до бажаної компетентності. На основі визначених критеріїв та показників окреслено рівні сформованості готовності бакалаврів з кібербезпеки до професійної діяльності. Виокремлено чотири рівні: початковий, середній, достатній та високий (Самойленко, Критерії формування готовності бакалаврів 3 кібербезпеки до професійної діяльності: педагогічний аспект, 2020). 
Бакалаврам з кібербезпеки подавалася технологія навчання у курсах такого типу. Зокрема, надавалися методики та електронний супровід, інтерактивні лекції, навчальні аудіокниги, презентації з профільних дисциплін, відеолекції, онлайн-трансляції, електронні он-лайн калькулятори, масове та дистанційне навчання, YouTube канали з інтерактивом для самоперевірки отриманих знань, мережеві тренажери для програмування, колаборативні освітні платформи, колаборативне навчання у мобільних додатках, колаборативні онлайнплатформи, віртуальні моделі і онлайн-лабораторії, тривимірна графіка середовища для візуального програмування, обробки даних, чат-боти.

Пропонувалися методики змішаного завчання з метою поєднання окремих модулів курсу дистанційної та аудиторної навчальної програми. Актуальними питаннями участі постали питання щодо проведення навчальних дискусій, диспутів, методів долання перешкод, методів проблемного викладу, а також евристичний (частково-пошуковий) метод, дослідницький метод, метод індивідуалізованого застосування програм залежно від особливостей бакалаврів, метод математичних та модельних гіпотез.

Результати. Дослідження здійснювалося нами 3 дотриманням низки вимог, основними 3 яких є такі: дотримання методики та термінів проведення експерименту (тривалість у часі, здійснення корекції організації та відтворення результатів); обгрунтування експериментальної бази дослідження. Експериментальна робота проводилася протягом п'яти років. В експерименті брало участь 879 бакалаврів з кібербезпеки. Розглянемо отримані результати сформованої готовності бакалаврів з кібербезпеки в умовах освітньо-цифрового середовища за визначеними критеріями у контрольних та експериментальних групах до і після експерименту.

Рівні сформованості готовності бакалаврів з кібербезпеки в умовах освітньо-иифрового середовища до професійної діяльності за мотивачійним критерієм у контрольних та експериментальних групах до і після експериментального дослідження представлені нижче (

Таблиця ). 
Рівні сформованості готовності бакалаврів з кібербезпеки в умовах освітньо-цифрового середовища до професійної діяльності за мотиваційним критерісм у контрольних та експериментальних групах до і після експериментального дослідження

\begin{tabular}{|c|c|c|c|c|}
\hline \multirow[b]{2}{*}{ Рівень } & \multicolumn{2}{|c|}{ До експерименту } & \multicolumn{2}{|c|}{ Після експерименту } \\
\hline & $\begin{array}{c}\text { К-сть відсотків } \\
\text { ЕГ до початку } \\
\text { експерименту }\end{array}$ & $\begin{array}{c}\text { К-сть відсотків } \\
\text { у КГ до } \\
\text { початку } \\
\text { експерименту }\end{array}$ & $\begin{array}{c}\text { К-сть відсотків } \\
\text { у ЕГ після } \\
\text { закінчення } \\
\text { експерименту }\end{array}$ & $\begin{array}{c}\text { К-сть відсотків } \\
\text { у КГ після } \\
\text { закінчення } \\
\text { експерименту }\end{array}$ \\
\hline Високий & 0,91 & 1,13 & 45,21 & 34,92 \\
\hline Достатній & 0,91 & 4,99 & 35,39 & 28,57 \\
\hline Середній & 18,95 & 21,77 & 13,24 & 13,83 \\
\hline Початковий & 74,20 & 72,11 & 6,16 & 22,68 \\
\hline Загальна кількість & 100,00 & 100,00 & 100,00 & 100,00 \\
\hline
\end{tabular}

Розглянемо отримані результати сформованої готовності бакалаврів 3 кібербезпеки в умовах освітньо-цифрового середовища за мотиваційним критерієм у контрольних та експериментальних групах до і після експерименту. Простежується приріст і в контрольних, і експериментальних групах, але показники контрольних груп значно перевищують показники експериментальних груп.

За мотиваційним критерієм по завершенню експерименту в рамках високого рівня в експериментальних групах приріст складає майже $50 \%$, в той час як у контрольних групах приріст не перевищує $35 \%$. На достатньому рівні в експериментальних групах показник складає $34,48 \%$, в той час як у контрольних - перевищує $25 \%$ на середньому рівні. В експериментальних групах показник зменшився на $5 \%$, в той час як у контрольних - зменшився на $8 \%$. На початковому рівні простежується зменшення в експериментальних групах на 68 \%, а в контрольних лише на $50 \%$.

В експериментальних групах такий приріст можна пояснити застосуванням в навчальному процесі таких методів, як навчальні дискусії, диспути, методи математичних та модельних гіпотез. Простежується 
зменшення на початковому та середньому рівні експериментальних групах значне підвищення на достатньому і високому.

Рівні сформованості готовності бакалаврів 3 кібербезпеки в умовах освітньо-цифрового середовища до професійної діяльності за інтеграційним критерієм у контрольних та експериментальних групах до i після експериментального дослідження представлено нижче (Таблиця ).

Таблиця 2.

Рівні сформованості готовності бакалаврів з кібербезпеки в умовах освітньо-цифрового середовища до професійної діяльності за інтеграційним критерісм у контрольних та експериментальних групах до і після експериментального дослідження

\begin{tabular}{|c|c|c|c|c|}
\hline \multirow[b]{2}{*}{ Рівень } & \multicolumn{2}{|c|}{ До експерименту } & \multicolumn{2}{|c|}{ Після експерименту } \\
\hline & $\begin{array}{c}\text { К-сть відсотків } \\
\text { у ЕГ до початку } \\
\text { експерименту }\end{array}$ & $\begin{array}{c}\text { К-сть відсотків } \\
\text { у КГ до } \\
\text { початку } \\
\text { експерименту }\end{array}$ & $\begin{array}{c}\text { К-сть відсотків } \\
\text { у ЕГ після } \\
\text { закінчення } \\
\text { експерименту }\end{array}$ & $\begin{array}{c}\text { К-сть відсотків } \\
\text { у КГ після } \\
\text { закінчення } \\
\text { експерименту }\end{array}$ \\
\hline Високий & 0,23 & 0,45 & 25,57 & 16,10 \\
\hline Достатній & 2,74 & 4,08 & 23,06 & 13,15 \\
\hline Середній & 10,50 & 7,94 & 42,69 & 36,51 \\
\hline Початковий & 86,53 & 87,53 & 8,68 & 34,24 \\
\hline Загальна кількість & 100,00 & 100,00 & 100,00 & 100,00 \\
\hline
\end{tabular}

Стан сформованості готовності бакалаврів 3 кібербезпеки в умовах освітньо-цифрового середовища до професійної діяльності за інтеграційним критерієм у контрольних та експериментальних групах по завершенню експериментального дослідження має приріст на високому, достатньому та середньому рівнях. Показники на початковому ж рівні зменшились.

По завершенню дослідження в експериментальній групі на високому рівні приріст складає майже $25 \%$, а у контрольних групах не перевищує $16 \%$. На достатньому рівні приріст в експериментальних групах на $20 \%$ перевищив приріст у контрольних групах. На середньому рівні показник експериментальних груп збільшився більше ніж на 30\%, що перевищує приріст в контрольних групах по завершенню експерименту на 6\%. На початковому рівні в експериментальних групах простежується зменшення показників майже 
на 80 \%, в той час як у контрольних групах показник зменшився більше ніж на $53 \%$.

Тобто на високому достатньому та середньому рівні В експериментальних групах вищі ніж у контрольних чи можна пояснити застосуванням таких засобів навчання як електронний супровід, інтерактивні лекції, навчальні аудіокниги та онлайн трансляції на основі принципів систематичності i послідовності. Рівні сформованості готовності бакалаврів 3 кібербезпеки в умовах освітньо-цифрового середовища до професійної діяльності за діяльнісно-операційним критерієм у контрольних та експериментальних групах до і після експериментального дослідження представлені нижче (Таблиця ).

Таблиця 3.

Рівні сформованості готовності бакалаврів з кібербезпеки в умовах освітньо-цифрового середовища до професійної діяльності за діяльнісноопераційним критерієм у контрольних та експериментальних групах до i після експериментального дослідження

\begin{tabular}{|c|c|c|c|c|}
\hline \multirow[b]{2}{*}{ Рівень } & \multicolumn{2}{|c|}{ До експерименту } & \multicolumn{2}{|c|}{ Після експерименту } \\
\hline & $\begin{array}{c}\text { К-сть відсотків } \\
\text { у ЕГ до початку } \\
\text { експерименту }\end{array}$ & $\begin{array}{c}\text { К-сть відсотків } \\
\text { у КГ до } \\
\text { початку } \\
\text { експерименту }\end{array}$ & $\begin{array}{c}\text { К-сть відсотків } \\
\text { у ЕГ після } \\
\text { закінчення } \\
\text { експерименту }\end{array}$ & $\begin{array}{c}\text { К-сть відсотків } \\
\text { у КГ після } \\
\text { закінчення } \\
\text { експерименту }\end{array}$ \\
\hline Високий & 1,14 & 0,91 & 18,95 & 13,15 \\
\hline Достатній & 5,71 & 4,31 & 22,37 & 9,75 \\
\hline Середній & 28,77 & 29,25 & 23,06 & 20,18 \\
\hline Початковий & 64,38 & 65,53 & 35,62 & 56,92 \\
\hline Загальна кількість & 100,00 & 100,00 & 100,00 & 100,00 \\
\hline
\end{tabular}

Стан сформованості готовності бакалаврів кібербезпеки в умовах освітніх цифрового середовища до професійної діяльності за діяльнісно-операційним критерієм у контрольних та експериментальних групах по завершенню експериментального дослідження засвідчують про приріст в експериментальних групах на високому і достатньому рівнях. Стан готовності бакалаврів 3 кібербезпеки в умовах освітньо-цифрового середовища до професійної діяльності за діяльнісно-операційним критерієм у контрольних та експериментальних групах до i після експериментального дослідження представлено нижче 
Приріст в експериментальних групах на високому рівні складає майже $17 \%$, в той час як в контрольних групах не перевищує $13 \%$. Приріст у в контрольних та експериментальних групах по завершенню експерименту складає майже 6 \%. На достатньому рівні приріст в експериментальних групах не перевищує $20 \%$, в той час як у контрольних групах не перевищує $6 \%$. Різниця приросту складає 12,62 \% на середньому рівні. В експериментальних групах прослідковується зменшення майже $5 \%$ Різниця приросту у контрольних та експериментальних групах складає 3 \%. В експериментальній групі на початковому рівні в експериментальних групах показник зменшився майже на 30 \%, в той час як у контрольних майже на $10 \%$.

Приріст закладає в основу принципи науковості наочності інтерактивності гуманізації та безперервності забезпечується на основі засобів дистанційного навчання YouTube каналів з інтерактивним для самоперевірки отриманих знань навчальних аудіокниг та презентації 3 профільних дисциплін. Експериментальне дослідження засвідчує приріст В експериментальних групах які принципово відрізняється від принципу контрольних.

Рівні сформованості готовності бакалаврів 3 кібербезпеки в умовах освітньо-цифрового середовища до професійної діяльності за творчим критерієм у контрольних та експериментальних групах до $\mathrm{i}$ після експериментального дослідження представлено нижче (Ошибка! Источник ссылки не найден.Таблиця 4).

Таблиця 4

Рівні сформованості готовності бакалаврів 3 кібербезпеки в умовах освітньо-цифрового середовища до професійної діяльності за творчим критерісм у контрольних та експериментальних групах до і після експериментального дослідження

\begin{tabular}{|l|c|c|c|c|}
\hline \multirow{2}{*}{ Рівень } & \multicolumn{2}{|c|}{ До експерименту } & \multicolumn{2}{c|}{ Після експерименту } \\
\cline { 2 - 5 } & $\begin{array}{c}\text { К-сть відсотків } \\
\mathbf{1} \text { ЕГ до початку } \\
\text { експерименту }\end{array}$ & $\begin{array}{c}\text { К-сть відсотків у } \\
\text { КГ до початку } \\
\text { експерименту }\end{array}$ & $\begin{array}{c}\text { К-сть відсотків у } \\
\text { ЕГ після } \\
\text { закінчення } \\
\text { експерименту }\end{array}$ & $\begin{array}{c}\text { К-сть відсотків у } \\
\text { КГ після } \\
\text { закінчення } \\
\text { експерименту }\end{array}$ \\
\hline Високий & 0,46 & 0,68 & 12,10 & 4,08 \\
\hline Достатній & 2,74 & 2,27 & 10,05 & 2,27 \\
\hline Середній & 22,60 & 23,58 & 20,78 & 1,36 \\
\hline
\end{tabular}




\begin{tabular}{|l|c|c|c|c|}
\hline Початковий & 74,20 & 73,47 & 57,08 & 92,29 \\
\hline Загальна кількість & 100,00 & 100,00 & 100,00 & 100,00 \\
\hline
\end{tabular}

Стан сформованості готовності бакалаврів 3 кібербезпеки в умовах освітньої цифрового середовища до професійної діяльності за творчим критеріям контрольних та експериментальних групах по завершенню експериментального дослідження також свідчить про приріст в експериментальних групах. Для більшої наочності результати у відсотковому відношенні представлені рисунком нижче.

Простежується зменшення показникового результату на початковому рівні в експериментальних групах майже на 20 \%, в той час як у контрольних групах підвищився майже на 20 \%. На середньому рівні в експериментальних групах простежується зменшення показників майже на 3 \%, в той час як у контрольних групах складає 1,36 \%. Приріст простежується на достатньому рівні більше ніж на $7 \%$, в той час як приросту в контрольних групах не простежується показник залишився незмінним. На високому рівні в експериментальних групах приріст складає майже 12 \%, у контрольних групах зафіксований приріст майже в $3 \%$. Різниця приросту складає 7,92\%.

Збільшення показників в експериментальних групах можна пояснити застосуванням методів індивідуалізованого застосування програм залежно від особливостей бакалаврів та таких засобів, як мережеві тренажери для програмування, колаборативні освітні платформи, колаборативне навчання у мобільних додатках, віртуальні моделі та онлайн лабораторії, тривимірна графіка, середовища для візуального програмування, обробка даних та робота 3 чат-ботами.

Перевіримо достовірність отриманих результатів сформованості готовності бакалаврів 3 кібербезпеки в умовах освітньо-цифрового середовища до професійної діяльності за мотиваційним критерієм за статистичним критерієм $\chi^{2}$ Пірсона після завершення експериментальної роботи в контрольній та експериментальній групах. Сформулюємо гіпотези: 
$\mathrm{H}_{\mathrm{o}}$ - не існує значних відмінностей у сформованості відповідних рівнів готовності бакалаврів 3 кібербезпеки в умовах освітньо-цифрового середовища до професійної діяльності у експериментальній та контрольній групі за мотиваційним критерієм.

$\mathrm{H}_{1}$ - існують значні відмінності в сформованості відповідних рівнів готовності бакалаврів з кібербезпеки в умовах освітньо-цифрового середовища у експериментальній та контрольній групі за мотиваційним критерієм.

Користуючись алгоритмом розрахунку емпіричного значення $\chi^{2}$, заповнимо таблицю розрахунку емпіричного значення $\chi^{2}$ за мотиваційним критерієм після завершення експерименту в контрольних та експериментальних групах (Таблиця 5).

Таблиця 5

\section{Розрахункова таблиця емпіричного значення $\chi^{2}$ за мотиваційним критерісм по завершенню експерименту в контрольних та експериментальних групах}

\begin{tabular}{|c|c|c|c|c|c|c|}
\hline \multirow{2}{*}{ Рівень } & \multicolumn{2}{|c|}{$\begin{array}{c}\text { Експериментальна група } \\
\text { (ЕГ) }\end{array}$} & \multicolumn{2}{|c|}{$\begin{array}{c}\text { Контрольна група } \\
\text { (КГ) }\end{array}$} & \multirow{2}{*}{$\begin{array}{c}\stackrel{2}{E} \\
\vdots \\
\Xi \\
\Xi\end{array}$} & \multirow{2}{*}{$=$} \\
\hline & $\begin{array}{c}\text { К-сть } \\
\text { відсотків }\end{array}$ & $\begin{array}{l}\text { Емпірична } \\
\text { частота } n_{i}\end{array}$ & $\begin{array}{c}\text { К-сть } \\
\text { відсотків }\end{array}$ & $\begin{array}{l}\text { Емпірична } \\
\text { частота } n_{i 1}\end{array}$ & & \\
\hline Високий & 45,21 & 198 & 34,92 & 154 & 1936 & 12,57 \\
\hline Достатній & 35,39 & 155 & 28,57 & 126 & 841 & 6,67 \\
\hline Середній & 13,24 & 58 & 13,83 & 61 & 9 & 0,15 \\
\hline Початковий & 6,16 & 27 & 22,68 & 100 & 5329 & 53,29 \\
\hline $\begin{array}{l}\text { Загальна } \\
\text { сума }\end{array}$ & 100,00 & 438 & 100,00 & 441 & & 72,68 \\
\hline $\mathrm{v}=\mathrm{k}-1$ & $4=2$ & , & 7,815 & $(p \leq 0,05)$ & & \\
\hline$k=4$ & $v=5$ & $\chi \cdot 2=$ & 11,345 & $(p \leq 0,01)$ & & \\
\hline
\end{tabular}

Емпіричне значення $\chi^{2}=72,68$. Критичне значення для ступені вільності $v=3$ Визначимо для даної ступені вільності критичне значення $\chi_{k p}^{2}$ для рівнів статистичної значущості $\rho \leq 0,05$ і $\rho \leq 0,01$ :

Отримані результати надають можливість зробити висновок: оскільки відхилення між розподілами незначні, а $\chi_{\text {емп }}^{2} \chi_{\text {кр., }}^{2}$ приймаємо гіпотезу $\mathrm{H}_{1}-$ існують значні відмінності в сформованості відповідних рівнів готовності 
бакалаврів 3 кібербезпеки в умовах освітньо-цифрового середовища у експериментальній та контрольній групі за мотиваційним критерієм по завершенню експерименту.

Перевіримо достовірність отриманих результатів сформованості готовності бакалаврів 3 кібербезпеки в умовах освітньо-цифрового середовища до професійної діяльності за інтеграційним критерієм за статистичним критерієм $\chi^{2}$ Пірсона після завершення експериментальної роботи в контрольній та експериментальній групах. Сформулюємо гіпотези:

$\mathrm{H}_{\mathrm{o}}$ - не існує значних відмінностей у сформованості відповідних рівнів готовності бакалаврів з кібербезпеки в умовах освітньо-цифрового середовища до професійної діяльності у експериментальній та контрольній групі за інтеграційним критерієм.

$\mathrm{H}_{1}$ - існують значні відмінності в сформованості відповідних рівнів готовності бакалаврів з кібербезпеки в умовах освітньо-цифрового середовища у експериментальній та контрольній групі за інтеграційним критерієм.

Користуючись алгоритмом розрахунку емпіричного значення $\chi^{2}$, заповнимо таблицю розрахунку емпіричного значення $\chi^{2}$ за інтеграційним критерієм після завершення експерименту в контрольних та експериментальних групах (Таблиця ).

Таблиця 6 Розрахункова таблиця емпіричного значення $\chi^{2}$ за інтеграційним
критерієм по завершенню експерименту в контрольних та експериментальних групах

\begin{tabular}{|c|c|c|c|c|c|c|}
\hline \multirow{2}{*}{ Рівень } & \multicolumn{2}{|c|}{$\begin{array}{c}\text { Експериментальна } \\
\text { група (ЕГ) } \\
\end{array}$} & \multicolumn{2}{|c|}{$\begin{array}{c}\text { Контрольна група } \\
(\text { КГ) }\end{array}$} & \multirow{2}{*}{ 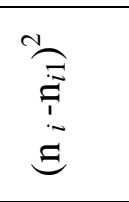 } & \multirow{2}{*}{ ت] } \\
\hline & $\begin{array}{c}\text { К-сть } \\
\text { відсотків }\end{array}$ & 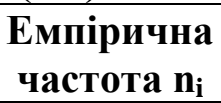 & $\begin{array}{c}\text { К-сть } \\
\text { відсотків }\end{array}$ & $\begin{array}{l}\text { Емпірична } \\
\text { частота } \mathbf{n}_{\text {i1 }}\end{array}$ & & \\
\hline Високий & 25,57 & 112 & 16,10 & 71 & 1681 & 23,68 \\
\hline Достатній & 23,06 & 101 & 13,15 & 58 & 1849 & 31,88 \\
\hline Середній & 42,69 & 187 & 36,51 & 161 & 676 & 4,20 \\
\hline Початковий & 8,68 & 38 & 34,24 & 151 & 12769 & 84,56 \\
\hline Загальна сума & 100,00 & 438 & 100,00 & 441 & & 144,32 \\
\hline$v=k-1$ & \multirow{2}{*}{$v=3$} & \multirow{2}{*}{$\chi^{\wedge} 2=$} & 7,815 & $(\mathrm{p} \leq 0,05)$ & & \\
\hline$k=4$ & & & 11,345 & $(p \leq 0,01)$ & & \\
\hline
\end{tabular}


Емпіричне значення $\chi^{2}=144,32$. Критичне значення для ступені вільності $v=3$ Визначимо для даної ступені вільності критичне значення $\chi_{k p}{ }^{2}$ для рівнів статистичної значущості $\rho \leq 0,05$ і $\rho \leq 0,01$ :

Отримані результати надають можливість зробити висновок: оскільки

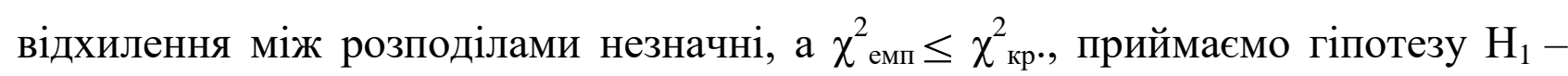
існують значні відмінності в сформованості відповідних рівнів готовності бакалаврів 3 кібербезпеки в умовах освітньо-цифрового середовища у експериментальній та контрольній групі за інтеграційним критерієм.

Перевіримо достовірність отриманих результатів сформованості готовності бакалаврів 3 кібербезпеки в умовах освітньо-цифрового середовища до професійної діяльності за діяльнісно-операційним критерієм за статистичним критерієм $\chi^{2}$ Пірсона після завершення експериментальної роботи в контрольній та експериментальній групах. Сформулюємо гіпотези:

$\mathrm{H}_{\mathrm{o}}$ - не існує значних відмінностей у сформованості відповідних рівнів готовності бакалаврів з кібербезпеки в умовах освітньо-цифрового середовища до професійної діяльності у експериментальній та контрольній групі за діяльнісно-операційним критерієм.

$\mathrm{H}_{1}$ - існують значні відмінності в сформованості відповідних рівнів готовності бакалаврів з кібербезпеки в умовах освітньо-цифрового середовища у експериментальній та контрольній групі за діяльнісно-операційним критерієм.

Таблиия 7

Розрахункова таблиця емпіричного значення $\chi^{2}$ за діяльнісноопераційним критерісм по завершенню експерименту в контрольних та експериментальних групах

\begin{tabular}{|c|c|c|c|c|c|c|}
\hline \multirow{2}{*}{ Рівень } & \multicolumn{2}{|c|}{$\begin{array}{c}\text { Експериментальна група } \\
\text { (ЕГ) }\end{array}$} & \multicolumn{2}{|c|}{$\begin{array}{c}\text { Контрольна група } \\
\text { (КГ) }\end{array}$} & \multirow{2}{*}{ 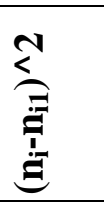 } & \multirow{2}{*}{ 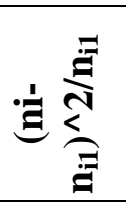 } \\
\hline & $\begin{array}{c}\text { К-сть } \\
\text { відсотків }\end{array}$ & $\begin{array}{l}\text { Емпірична } \\
\text { частота } \mathrm{n}_{\mathrm{i}}\end{array}$ & $\begin{array}{c}\text { К-сть } \\
\text { відсотків }\end{array}$ & $\begin{array}{l}\text { Емпірична } \\
\text { частота } \mathbf{n}_{\text {i1 }}\end{array}$ & & \\
\hline Високий & 18,95 & 83 & 13,15 & 58 & 625 & 10,78 \\
\hline Достатній & 22,37 & 98 & 9,75 & 43 & 3025 & 70,35 \\
\hline Середній & 23,06 & 101 & 20,18 & 89 & 144 & 1,62 \\
\hline Початковий & 35,62 & 156 & 56,92 & 251 & 9025 & 35,96 \\
\hline Загальна сума & 100,00 & 438 & 100,00 & 441 & & 118,70 \\
\hline $\mathrm{v}=\mathrm{k}-1$ & $v=3$ & $\chi^{\wedge} 2=$ & 7,815 & $(p \leq 0,05)$ & & \\
\hline
\end{tabular}


Користуючись алгоритмом розрахунку емпіричного значення $\chi^{2}$, заповнимо таблицю розрахунку емпіричного значення $\chi^{2}$ за діяльнісноопераційним критерієм після завершення експерименту в контрольних та експериментальних групах (Таблиця ).

Емпіричне значення $\chi^{2}=118,70$. Критичне значення для ступені вільності $v=3$ Визначимо для даної ступені вільності критичне значення $\chi_{k p}{ }^{2}$ для рівнів статистичної значущості $\rho \leq 0,05$ і $\rho \leq 0,01$ :

Отримані результати надають можливість зробити висновок: оскільки відхилення між розподілами незначні, а $\chi_{\text {емп }}^{2} \leq \chi_{\text {кр. }}^{2}$, приймаємо гіпотезу $\mathrm{H}_{1}-$ існують значні відмінності в сформованості відповідних рівнів готовності бакалаврів 3 кібербезпеки в умовах освітньо-цифрового середовища у експериментальній та контрольній групі за діяльнісно-операційним критерієм по завершенню експерименту.

Перевіримо достовірність отриманих результатів сформованості готовності бакалаврів 3 кібербезпеки в умовах освітньо-цифрового середовища до професійної діяльності за творчим критерієм за статистичним критерієм $\chi^{2}$ Пірсона після завершення експериментальної роботи в контрольній та експериментальній групах. Сформулюємо гіпотези:

$\mathrm{H}_{\mathrm{o}}$ - не існує значних відмінностей у сформованості відповідних рівнів готовності бакалаврів з кібербезпеки в умовах освітньо-цифрового середовища до професійної діяльності у експериментальній та контрольній групі за творчим критерієм.

$\mathrm{H}_{1}$ - існують значні відмінності в сформованості відповідних рівнів готовності бакалаврів з кібербезпеки в умовах освітньо-цифрового середовища у експериментальній та контрольній групі за творчим критерієм.

Користуючись алгоритмом розрахунку емпіричного значення $\chi^{2}$, заповнимо таблицю розрахунку емпіричного значення $\chi^{2}$ за творчим критерієм 
після завершення експерименту в контрольних та експериментальних групах (Таблиця ).

Таблиця 8

Розрахункова таблиця емпіричного значення $\chi^{2}$ за творчим критерісм по завершенню експерименту в контрольних та експериментальних групах

\begin{tabular}{|c|c|c|c|c|c|c|}
\hline \multirow{2}{*}{ Рівень } & \multicolumn{2}{|c|}{$\begin{array}{c}\text { Експериментальна група } \\
(\text { (ЕГ) }\end{array}$} & \multicolumn{2}{|c|}{$\begin{array}{c}\text { Контрольна група } \\
\text { (КГ) }\end{array}$} & \multirow{2}{*}{ 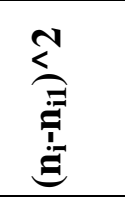 } & \multirow{2}{*}{ 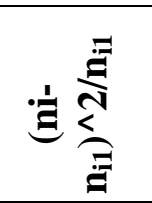 } \\
\hline & $\begin{array}{c}\text { K-сть } \\
\text { відсотків }\end{array}$ & $\begin{array}{l}\text { Емпірична } \\
\text { частота } \mathbf{n}_{\mathbf{i}}\end{array}$ & $\begin{array}{c}\text { К-сть } \\
\text { відсотків }\end{array}$ & $\begin{array}{l}\text { Емпірична } \\
\text { частота } \mathbf{n}_{\text {i1 }}\end{array}$ & & \\
\hline Високий & 12,10 & 53 & 4,08 & 18 & 1225 & 68,06 \\
\hline Достатній & 10,05 & 44 & 2,27 & 10 & 1156 & 115,60 \\
\hline Середній & 20,78 & 91 & 1,36 & 6 & 7225 & 1204,17 \\
\hline Початковий & 57,08 & 250 & 92,29 & 407 & 24649 & 60,56 \\
\hline $\begin{array}{l}\text { Загальна } \\
\text { сума }\end{array}$ & 100,00 & 438 & 100,00 & 441 & & 1448,38 \\
\hline $\mathrm{v}=\mathrm{k}-1$ & \multirow{2}{*}{$v=3$} & \multirow{2}{*}{$\chi^{\wedge} 2=$} & 7,815 & $(p \leq 0,05)$ & & \\
\hline$k=4$ & & & 11,345 & $(p \leq 0,01)$ & & \\
\hline
\end{tabular}

Емпіричне значення $\chi^{2}=1448,38$. Критичне значення для ступені вільності v=3 Визначимо для даної ступені вільності критичне значення $\chi_{k p}^{2}$ для рівнів статистичної значущості $\rho \leq 0,05$ і $\rho \leq 0,01$ :

Отримані результати надають можливість зробити висновок: оскільки

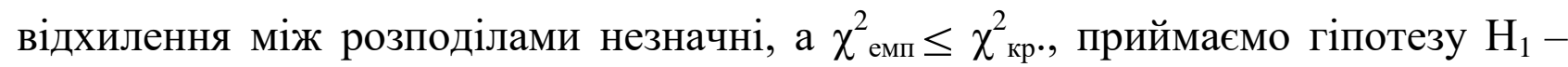
існують значні відмінності в сформованості відповідних рівнів готовності бакалаврів 3 кібербезпеки в умовах освітньо-цифрового середовища у експериментальній та контрольній групі за творчим критерієм по завершенню експерименту.

Дискусія. Експериментальна робота проводилася протягом п’яти років. В експерименті брало участь 879 бакалаврів з кібербезпеки. Формувальний етап експериментального дослідження передбачав багатофакторність предмету дослідження. Теоретичні та методичні основи професійної підготовки бакалаврів 3 кібербезпеки в умовах освітньо-цифрового середовища зумовлюють впровадження комплексного педагогічного експерименту, який 
дозволив би найбільш грунтовно виявити досягнення і недоліки, простежити причинно-наслідкові зв'язки, визначити внутрішні джерела розвитку досліджуваної проблеми, з'ясувати впливові чинники та детермінанти їх професійної підготовки.

Логічна схема цього етапу експериментального дослідження включала таку послідовність: 1) констатація на діагностичній основі рівня сформованості професійної спрямованості та ступеня мотивації на професійний і особистісний розвиток; 2) здійснення експериментально-формувального впливу на процес оволодіння складовими професійної підготовки бакалаврів з кібербезпеки через практичне впровадження у навчальний процес конструктивної моделі підготовки бакалаврів з кібербезпеки в умовах освітньо-цифрового середовища; 3) виявлення динаміки сформованості готовності майбутніх бакалаврів 3 кібербезпеки на основі порівняння сумарних показників, отриманих у процесі діагностики рівня сформованості їі складових на різних етапах експерименту.

Подальші напрямки досліджень спрямовані на удосконалення моделі підготовки не тільки бакалаврів, а і магістрів з кібербезпеки в умовах освітньоцифрового середовища, іiі впровадженні в навчальний процес та удосконалені результатів.

Висновок. Таким чином, отримані результати формувального етапу педагогічного експерименту щодо впровадження моделі підготовки бакалаврів 3 кібербезпеки в умовах освітньо-цифрового середовища надають можливість стверджувати, що простежується позитивна динаміка в процесі формування готовності. Розроблена модель підготовки бакалаврів підвищує рівень їх умотивованості на професійну підготовку та отримання закордонного досвіду, а також самостимулювання щодо набуття фахових компетентностей в умовах освітньо-цифрового середовища, про що свідчить відсотковий приріст в експериментальних групах. Перспективами подальиих досліджень будемо вважати розробку методики застосування освітньо-цифрового середовища в системі професійної підготовки магістрів 3 кібербезпеки. 


\section{СПИСОК ЛІТЕРАТУРИ}

Самойленко, О. О. (2016). Методологічні підходи щодо управління консорціумом інститутів післядипломної педагогічної освіти в умовах єдиного інформаційного простору. Нові технології навчання: наук.-метод. зб.; Інститут інноваційних технологій $і$ змісту освіти МОН Украйни(88 ч. 2), $56-61$.

Самойленко, О. О. (2020). Конструктивна модель підготовки бакалаврів 3 кібербезпеки в умовах освітньо-цифрового середовища. Вісник Черкаського національного університету імені Богдана Хмельнииького Серія «Педагогічні науки»(2), 102-106. doi:10.31651/2524-2660-2020-2-102-106

Самойленко, О. О. (2020). Критерії формування готовності бакалаврів 3 кібербезпеки до професійної діяльності: педагогічний аспект. Impact of modernity on science and practice. Abstracts of XII international scientific and practical conference, 592-595. Едмонтон, Канада .

Самойленко, О. О. (2020). Методологічні підходи щодо підготовки бакалаврів 3 кібербезпеки в умовах освітньо-цифрового середовища. Науковий журнал «Інновачійна педагогіка», 3(22), 95-99. doi:doi.org/10.32843/2663-6085

\section{REFERENCES}

Samojlenko, O. O. (2016). Metodologi`chni` pi`dkhodi shhodo upravli`nnya konsorczi umom i`nstituti $v$ pi`slyadiplomnoyi pedagogi 'chnoyi osvi ti $\mathrm{v}$ umovakh yedinogo i'nformaczi jnogo prostoru [Methodological approaches to the management of the consortium of institutes of postgraduate pedagogical education in the conditions of a single information space]. Novi` tekhnologi yi navchannya: nauk.metod. zb.; I’nstitut i`nnovaczi`jnikh tekhnologi`j i zmi`stu osvi`ti MON Ukrayini (88 ch. 2), 56-61.

Samojlenko, O. O. (2020). Konstruktivna model pi`dgotovki bakalavri`v z ki berbezpeki v umovakh osvi tn`o-czifrovogo seredovishha [Constructive model of training bachelors in cybersecurity in an educational and digital environment]. Vi`snik Cherkas`kogo naczi`onal’nogo uni`versitetu i`meni Bogdana Khmel`nicz`kogo Seri`ya «Pedagogi`chni` nauki»(2), 102-106. doi:10.31651/25242660-2020-2-102-106

Samojlenko, O. O. (2020). Kriteri yi formuvannya gotovnosti` bakalavri`v z ki`berbezpeki do profesi jnoyi di`yal’nosti`: pedagogi`chnij aspekt [Criteria for forming the readiness of bachelors in cybersecurity for professional activity: pedagogical aspect]. Impact of modernity on science and practice. Abstracts of XII international scientific and practical conference, 592-595. Edmonton, Kanada .

Samojlenko, O. O. (2020). Metodologi`chni` pi`dkhodi shhodo pi`dgotovki bakalavri`v $\mathrm{z}$ ki berbezpeki $\mathrm{v}$ umovakh osvi tn`o-czifrovogo seredovishha [Methodological approaches to the training of bachelors in cybersecurity in an educational and digital environment]. Naukovij zhurnal «Innovaczi jna pedagogi` ka», 3(22), 95-99. doi:doi.org/10.32843/2663-6085 


\title{
O. Samoylenko
}

ANALYSIS OF THE RESULTS OF THE FORMATIVE STAGE OF THE PEDAGOGICAL EXPERIMENT ON THE INTRODUCTION OF THE MODEL OF BACHELOR TRAINING IN CYBER SECURITY IN THE CONDITIONAL AND DIGITAL ENVIRONMENT

\begin{abstract}
The article presents an analysis of the results of the formative stage of the pedagogical experiment on the implementation of the model of training bachelors in cybersecurity in an educational and digital environment. It is noted that bachelors in cybersecurity were provided with training technology in courses of this type, in particular, provided methods and electronic support, interactive lectures, audiobooks, presentations on specialized disciplines, video lectures, online broadcasts, electronic online calculators, mass and distance learning, YouTube channels with interactive self-assessment, online programming simulators, collaborative educational platforms, collaborative learning in mobile applications, collaborative online platforms, virtual models and online labs, three-dimensional graphics environment for visual programming, data processing, chatbots. The study was carried out in compliance with a number of requirements, the main of which are: compliance with the methodology and timing of the experiment (duration in time, the implementation of the correction of the organization and reproduction of results); substantiation of the experimental base of the research. The experimental work was carried out for five years. 879 bachelors in cybersecurity took part in the experiment. The obtained results of the formed readiness of bachelors in cybersecurity in the conditions of educational and digital environment according to certain criteria in control and experimental groups before and after the experiment are considered. Levels of readiness of bachelors in cybersecurity in the educational-digital environment for professional activity by motivational, integration, activityoperational and creative criteria in control and experimental groups before and after experimental research are presented in the form of spreadsheets. The obtained results of the experimental study provide an opportunity to assert that the constructive model of training bachelors in cybersecurity in the educational-digital environment is effective.
\end{abstract}

Keywords: bachelor in cybersecurity; constructive model of training; model; educational-digital environment; pedagogical experiment; environment. 